\title{
Students' Need Analysis on English Learning Material at Mechanical Metal in SMK N 8 Padang
}

\author{
HEVRIANI SEVRIKA \\ English Department, STKIP PGRI West Sumatera. Jln. Gunung Pangilun. Padang. \\ 25144. Indonesia. \\ E-mail: sevrikariechaegmail.com
}

\begin{abstract}
Mechanical students need material in English subject that relevant with their department. However, most of the teachers used the materials that are general English to teach English in the mechanical department. Thus, in this research the writer did it to know the students' need. In this research, the samples are the students in the mechanical metal department. There are two classes which are 45 students. The writer took 15 students through technique sampling is sample random sampling. The instrument that writer used to take the data is questionnaires through open - ended questions. The students need in learning English can be seen in three aspects: necessities, lacks, and wants. The first aspect is necessity, the finding is the students need English materials that are easy to be understood by them. They need the words of the text which are simple and easy to be understood. The second aspect is lack that the students' lacks are they have fewer vocabularies, so they are difficult to understand the texts. The last aspect is wants; they want to have fluency in speaking so they need to have more activities in speaking skill. Otherwise, the teacher rarely gave speaking skill in teaching and learning process. Thus, the teachers need to know what are the students need to be learned in their departments.
\end{abstract}

Keywords - Student's need; Learning Material

\section{INTRODUCTION}

ESP (English for Specific Purposes) is the English that is taught to the students with the specific subject, such as engineering, mechanical metal, economic, medical, accountant, law, and etc. According to Day and Krzanowski (2011:5), ESP (English for Specific Purposes) involves teaching and learning the specific skills and language needed by particular learners for a particular purpose. It defines that in running ESP program needs to analyze who needs ESP and how the language uses for students. Then, ESP program adjusting the purposes with academic and occupation based on the result of need analysis as a systematic and comprehensive. Need analysis means as a phase in gathering the data on what the students need on learning material which identifying the language that students will need and how the students' knowledge in present situation.

This research is very important to be done to get more and deep information about the students' needs in learning English because most of the teachers only use the books as sources of materials through the text book. The text books generally contain English materials generally such as: text about industry, conversation about greeting in business, and etc, but the students who come from different departments, so they will need materials based on their departments. For example; if the students department is Technique Informatics Computer (TIK), they will need all the materials relate about how to operate computers, applications in the computers, and correspondence through e mail. Difference with the students of technique electricity, they will need to learn the English words and everything that taught about electricity.

In real condition, English for Specific Purposes has not applied yet at Vocational High School and it occurs as English for General. Referring to preobservation on students' need analysis on English learning material which have been done by the researcher in Mechanical Metal department of SMKN 8 Padang, the researcher found that English learning material which received by the students, it is not based on the analysis of the students' need. It is because, the learning material based on the curriculum of KTSP on the syllabus that almost all 
of the learning material are general such as learning about daily conversation, direct interaction in hotel, use expression in giving compliment, expression to show opinion although there is material that appropriate to students' course that is the procedure in describing how things are operated. It explained that almost English materials are general, while the courses at SMKN 8 Padang are technical.

From the problem that present in this study, the researcher plans to analyze students' need on English learning material at Mechanical Metal of SMKN 8 Padang, and the researcher gets a conclusion that students' need on English learning material at Vocational High School especially in Mechanical Metal that have to view in deep in order what the students' receive is significant to the students' life in academic, daily activities and in their occupation in the future.

\section{METHODS}

\section{A. STUDENTS NEED}

Every student generally has the same needs. They need to get knowledge in teaching learning process, and they need to be understood by the teachers. There are some experts who discuss about students need. First, Mercer and Joan (1996: 284) defines the students need that students need to learn how to operate with English speakers or in English - speaking countries to become culturally competent' as well as communicatively competent. It means that the students in learning English need to have much vocabularies and knowledge about using vocabularies, pronunciation, and structure, so they can use them in speaking English, and they can communicate and speak English with native or the English speakers.

Then, Swan and Catherine (1990: IX) define that students need is the students need to learn the language used to talk about the subjects of general interests. The experts talk that the students need to learn a language to get knowledge about the general interest which is the situation and context of the materials describe and use in the real context and situation of native speakers. For example: if the text talks about greeting, they need to get real conversation that the speakers say when they meet someone and greet each other.

Moreover, Coniam (2014: 38) states students need to have a solid foundation in linguistic knowledge, on which competence could be further, developed. The solid foundation that they need is vocabularies. If they do not know the meaning of vocabularies, there are no words to be told to others. They will need vocabularies in all the skills; listening, speaking, reading, and writing.

Next, Prain et al (2015: 117) explain that there are some student's needs. First, students need to understand that they have to justify and explain their decisions and thinking in class. Second, students' need multiple and differently contextualized opportunities for guided practice. Third, students need guided support to practice in purposeful inquiry that entails creative and critical thinking. Therefore, the students need to be understood by the teachers in teaching and learning process. They need to convey their opinion, ideas, and support from the teachers. They are people who need help from teachers.

In summarizing, the students have some need in learning. The needs can be classified in two aspects; need knowledge and need support and understandable by the teachers. Needs' knowledge as the language learners are knowledge about the language components (vocabulary, pronunciation, and structure) and skills (listening, speaking, reading, and writing). Then, need understandable that is the teachers should understand what they need and interest in learning.

\section{B. ESP (ENGLISH for SPECIFIC PURPOSES)}

The students learn ESP to get the knowledge about English in their department. Tomlinson (2003:306) defines that English for Specific Purposes (ESP) is an umbrella term that refers to the teaching of English to the students who are learning the language for a particular work or study-related reason. English has so many vocabularies. Every single word in Indonesia has so many words in English, and every single word in English has so many words in Indonesia. The words will have different meanings if the context are difference, so if the students learn English for Specific Purpose that are based on their department, so they will have difference need to be learned. Every particular work or study will need and use English in difference context, such as English for Business, English for Medical, and English for Engineering and Mechanical, English for Tourism, English for Journalist, and etc.

Furthermore, Byram (2000:285) states that English for Specific Purposes (ESP) refers to the teaching and learning of English for an instrumental 
purposes-work or study related-and embraces a great diversity of language teaching and learning situations around the world.

The students who learn ESP need the materials that are the text, and conversation in their field. If the students' department is engineering, so they need the text and conversation that talk about engineering and the situation how to behave in the engineering workplace. Then, if they are medical students, so they need the text that is content about medical and the situation in the hospital. Next, if they are accountant students, so they will need to learn the text in the business and accountancy context. And the same with other field students, they will have difference need to be learned.

The students learn English for Specific Purpose can be seen based on their need, so the teachers or educators should do need analysis to get the specific information based on their needs. Chambers (in Basturkmen2010:18) describes that need analysis should be concerned with the establishment of communicative needs and their realizations, resulting from an analysis of the communication in the target situation - what I will refer to as target situation analysis. In communicative needs, the students study English only for communication. The English that are used for communication is difference with English for written, because in the written context the English is used structurally and grammatically. However, the English for spoken can be flexible. Then, an analysis of the communication in the target situation is the materials that are given by educators or teachers should base on the students need which they come from in difference department and particular work.

Moreover, Robinson (1991:7) states that sometimes needs can be interpreted as inadequacies to be filled, like what the learners currently cannot do or do not know about the language. The students come from difference social environment, so they will have difference background knowledge. The teachers should analyze what their students know and do before they learn. It can be done by the teachers through brainstorming step in teaching learning process that the teachers can ask some questions about the topic that are going to be discussed. Then, the teacher should analyze what the students do not know and do after they learn. The teacher can do this through assess them.
The students' need can be clarified into some types, such as necessities, lacks, and wants. The first type is Students' Necessities, Richards (1990:180) state that necessity is need determined by the target situation: that is what the learners need to know and be able to do function effectively in target situation. The students who come from particular work or study, they need to learn English based on their work or study, because the words or terms that are used for particular work or subjects are difference with general English. If the students will work in business, they will need the English vocabulary in the business

The second type is students' lacks. Macalister (2010:25) states that lacks fit into present knowledge. It defines that students' lacks discuss about how the view of existing knowledge which students have. In analyzing the students' lacks, the teacher needs to gather the data about the lack of students' knowledge. In this case, how the necessities provide and cover the students' existing knowledge in English learning material. The teacher can get information and know about this through assess the students in the teaching and learning process. Through the assessment that is given by the teachers, the teachers can adapt the materials based on their needs.

The last type is students' wants. Macalister (2010:25) states that wants fit into subjective needs. Every student learns English as generally to get knowledge. In specific, their wants are difference. First, their wants will be difference if they come from difference work or department. Second, they want to learn English to make they can speak English. Next, they want to have many vocabularies, so they can understand easily to read the English texts or books.

Every student need can be given through learning material. Tomlinson (2001:66) states that 'Materials' include anything which can be used to facilitate the learning of a language. The materials should contain knowledge and information that are the newest and truly, so the students interest and have curiosity to learn and receive the materials.

\section{FINDINGS AND INTERPRETATION}

The Findings of this research can be categorized in some indicators of the research. It can be seen as follow;

\section{Necessities}


The Demands of Target Situation. The students needed have a good communication in English and support English skill in working. English skill that students' needed at Mechanical Metal was speaking in order the students could communicate and increase the higher speaking skill.

Fit Into Required Knowledge. The appropriateness English is which applied in Mechanical Metal was not appropriate yet because the students were difficult in understanding English and they were not mastering the vocabulary yet. Moreover, English was not applied as English for technical yet.

The Learners Need to Know in Target Situation. The students needed the material about daily activity because daily activity was easy to be understood by them. In teaching and learning process, the students needed to learn by practiced in front of the class and the teacher explained the material.

Able to do Function Effectively in Target Situation. The students often had group work in studying English because they could learn together.

\section{Lacks}

What the Learners Know Already. The English at Mechanical Metal department enough appropriated because the students learned English in metal. The students' understanding about English was less because they had problem in mastering vocabulary.

Fit Into Present Knowledge. The assignment difficulty level which is given by teacher was in categorized easy, to difficult and usual with the reason because the students did together in group and could search in internet, it was difficult because less understanding and it was usual because the material already repeated and still could be understood. It defined among these were balance.

The Gap Between Target Situation and Existing Knowledge. The students' problem in learning English was speaking, because they have less in vocabulary and pronunciation. The students' problem in understanding English material was not mastering the vocabulary and got difficult in pronunciation.

\section{Wants}

Objective Needs. The students wanted speaking skill as the main point which the students'like. The students wanted the material that related to work because it would make the students easy to came to industrial and help them in working. The students liked English material related to their department in the mechanical metal because the students could get the vocabulary and they can use it in the English communication in their workplace.

Subjective Needs. The students wanted studying English to support in working because they hoped it would support the students in working after they graduated from Mechanical Metal department. In studying English the students wanted to be master in English conversation. The students wanted they could speak English well in working after graduated from Mechanical Metal department. The students liked the teacher's style if the teacher way to explain the material and asked the students to practice in front of the class because the students will ne easy to understand by the students to speak English therefore they had self confident.

The data is taken through given questioners to 15 students that are taken in the simple random sampling technique from 45 students. The researcher interpreted the data analyzed to the students need' on English learning material that focused on necessities, lacks and wants. The interpretation as followed:

TABLE I

FINDING OF THE RESEARCH

\begin{tabular}{|c|c|c|}
\hline Needs & Indicators & Findings \\
\hline Necessities & $\begin{array}{l}\text { The Demands } \\
\text { of the Target } \\
\text { Situation }\end{array}$ & $\begin{array}{l}\text { In learning English, } \\
\text { the students needed } \\
\text { have a good } \\
\text { communication in } \\
\text { English and support } \\
\text { English skill in } \\
\text { working. } \\
\text { English skill that } \\
\text { students' needed at } \\
\text { Mechanical Metal } \\
\text { was speaking in } \\
\text { order the students } \\
\text { could communicate } \\
\text { and increase the } \\
\text { higher speaking } \\
\text { skill. }\end{array}$ \\
\hline & $\begin{array}{l}\text { Fit into } \\
\text { Required } \\
\text { Knowledge }\end{array}$ & $\begin{array}{l}\text { English which } \\
\text { applied in } \\
\text { Mechanical Metal } \\
\text { was not appropriate } \\
\text { yet because the } \\
\text { students were } \\
\text { difficult } \\
\text { understanding } \\
\text { English and they } \\
\text { were not mastering } \\
\text { the vocabulary yet. } \\
\text { Moreover, English } \\
\text { was not applied as } \\
\text { English for technical } \\
\text { yet. }\end{array}$ \\
\hline
\end{tabular}




\begin{tabular}{|c|c|c|}
\hline & $\begin{array}{ll}\text { The Learners } \\
\text { Need to Know } \\
\text { In } \\
\text { Situation }\end{array}$ & $\begin{array}{l}\text { The students needed } \\
\text { the material about } \\
\text { daily activity } \\
\text { because daily } \\
\text { activity was easy. } \\
\text { In teaching and } \\
\text { learning process the } \\
\text { students needed to } \\
\text { learn by practiced in } \\
\text { front of the class and } \\
\text { the teacher explained } \\
\text { the material. }\end{array}$ \\
\hline & $\begin{array}{l}\text { Able to do } \\
\text { Function } \\
\text { Effectively in } \\
\text { Target Situation }\end{array}$ & $\begin{array}{l}\text { The learning style } \\
\text { that students needed } \\
\text { was listening the } \\
\text { teachers' } \\
\text { explanation. } \\
\text { The students often } \\
\text { had group work in } \\
\text { studying English } \\
\text { because they could } \\
\text { learn together. }\end{array}$ \\
\hline \multirow[t]{2}{*}{ Lacks } & $\begin{array}{cr}\text { What } & \text { the } \\
\text { Learner } & \text { knows } \\
\text { Already } & \end{array}$ & $\begin{array}{l}\text { English at } \\
\text { Mechanical Metal } \\
\text { department enough } \\
\text { appropriated because } \\
\text { the students learned } \\
\text { English in drawing. } \\
\text { The students had less } \\
\text { understanding about } \\
\text { English because they } \\
\text { were not mastering } \\
\text { the vocabulary. } \\
\text { The students' } \\
\text { understanding about } \\
\text { English was less } \\
\text { because they had } \\
\text { problem in } \\
\text { mastering } \\
\text { vocabulary. }\end{array}$ \\
\hline & $\begin{array}{l}\text { Fit into Present } \\
\text { Knowledge }\end{array}$ & $\begin{array}{l}\text { In English teaching } \\
\text { and learning process, } \\
\text { the teacher's } \\
\text { explanation was easy } \\
\text { to be understood. } \\
\text { The assignment } \\
\text { difficulty level } \\
\text { which given by } \\
\text { teacher was in } \\
\text { categorize easy, } \\
\text { difficult and usual } \\
\text { with the reason } \\
\text { because the students } \\
\text { did together in group } \\
\text { and could search in } \\
\text { internet, it was } \\
\text { difficult because the } \\
\text { students less } \\
\text { understanding and it } \\
\text { was usual because } \\
\text { the material already } \\
\text { repeated and still } \\
\text { could be understood. } \\
\text { It defined among } \\
\text { these were balance }\end{array}$ \\
\hline Wants & $\begin{array}{l}\text { Objective } \\
\text { Needs (Students } \\
\text { Wants on }\end{array}$ & $\begin{array}{l}\text { The students wanted } \\
\text { speaking skill as the } \\
\text { main point which the }\end{array}$ \\
\hline
\end{tabular}

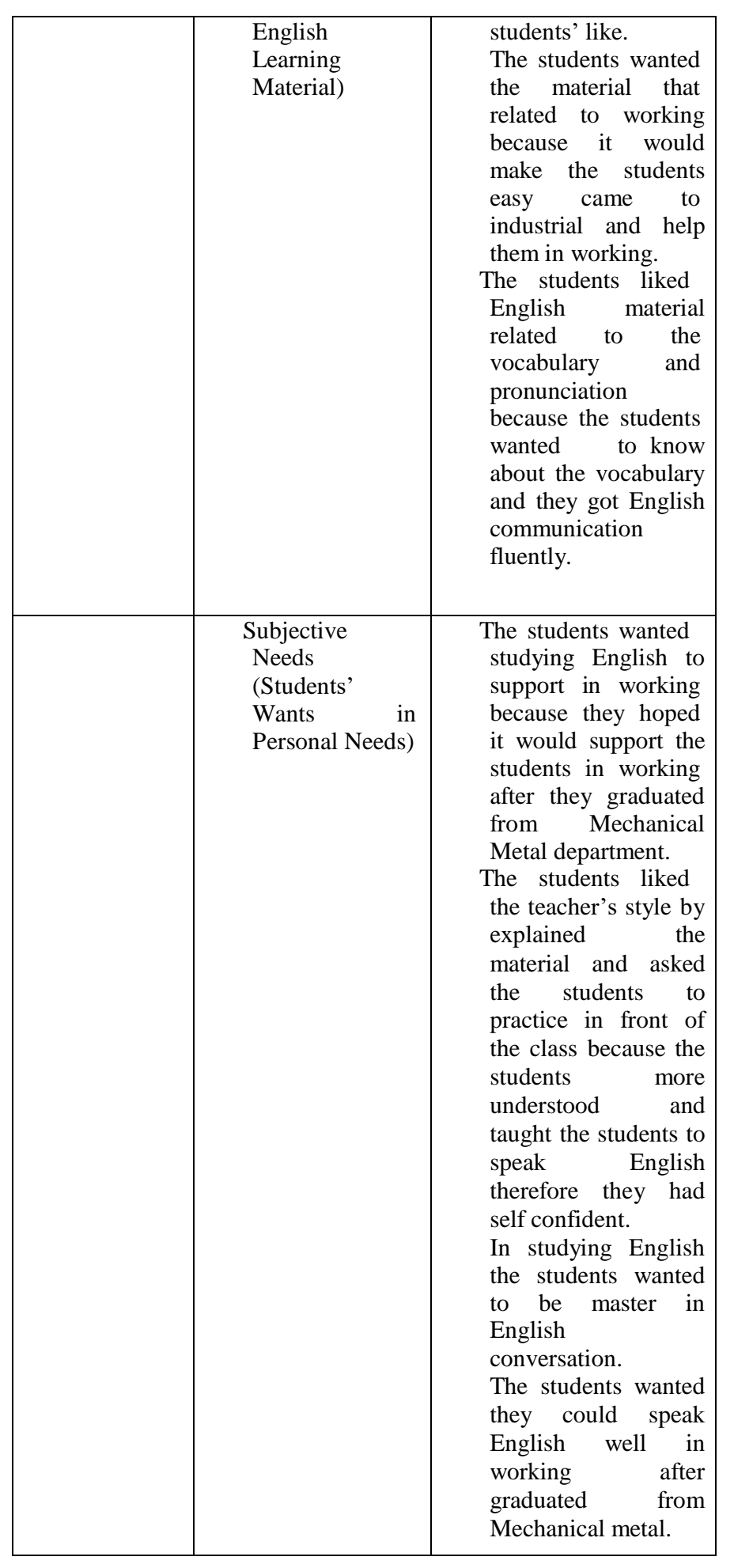

\section{Necessities}

In the necessities categorize, the researcher interpreted the result of this research. First, English was useful for the students in getting good communication well in working field. Then, speaking was skill which really students' needed because the students had to have a good skill in communication. Next, the student needed in English was not completed yet because English was 
not appropriate yet. Moreover, English material needed by students was material that useful for the students' activities. Furthermore, learning style that students want was teacher center because the material had learned was difficult for the students. Last, the students needed group work to finish assignment which distributed by the teacher because they could finish the assignment together. Thus, the students' necessities are the materials that relate with their metal department. They need materials or text that discuss in the Metal Department contexts, but the teachers only use and give the materials about language generally.

\section{Lacks}

In the lacks categorize, it could be interpreted that the students' understanding about English was weak because they did not understand English yet. Then, the students could understand the teacher's explanation, but the students were not fluently in speaking English yet. Moreover, the level's assignment difficulty which made by teacher well done because the teacher made it in category easy, usual and difficult. However, the material which is given was not fulfilling the students' need in learning English. Furthermore, the students' needed in English was speaking skill especially in mastering vocabulary and pronunciation. Because, the students expected to have a good English communication in working field. Therefore, from the finding of these questionnaires the students have lack of vocabularies, so they difficult to understand the materials that are taught by the teachers. They have lack of vocabularies, because the teachers do not teach and give many vocabularies to the students in teaching.

\section{Wants}

In categorized wants, the students'want in English was to help them in working field after the they graduated from Mechanical Metal. Then, In English teaching and learning process, the teacher should explain the material clearly because the students want to speak English fluently. Thus, in this research they need the texts that are contains the materials about metal.

Based on three categorizes necessities, lacks and wants, the researcher concluded that the result from students' need analysis at Mechanical Metal department of SMK N 8 Padang that the students needed learning material which is easy to be understood. Thus, they could understand English more and the students could speak in English fluently to get easier in working field. Then, the students' lacks categorize were the students did not understand English yet, because they did not master vocabulary and pronunciation. And, the last students' wants that the students wanted to speak English fluently and had a good communication in working after they graduated from Mechanical Metal department.

\section{CONCLUSIONS}

In summarizing, the students in the vocational school need English to be mastered as the pre learning to come to the real situation in the workplace. Especially, for students at SMKN 8 Padang, they need to learn English that can be seen in three aspects: necessities, lacks, and wants. The first aspect is necessities. The students need to be taught with the topic about Engineering mental. The second aspect is lacks; the students have lacks of vocabulary, so they difficult to speak English and to understand the written text. The last aspect is want; they want the teacher use the text with the simple and easy vocabularies to be understood. Thus, the students need to be understood by their teachers and can teach English communicatively to make them have a chance to speak in English.

\section{REFERENCES}

[1] Basturkmen H. 2010. Developing Courses in English for Specific Purposes.Great Britain: Palgrave Macmillan.

[2] Byram M \&Adelheid Hu. 2000. Language Teaching and Learning. New York: Routledge.

[3] Coniam, David. 2014. English Language Education and Assessment. Hongkong : Springer.

[4] Day J \& Krzanowski M. 2011. Teaching English for Specific Purposes: An Introduction.Cambridge: Cambridge University Press.

[5] Macalister J. 2010. Language Curriculum Design. New York: Routledge.

[6] Mercer, Neil \& Joan Swann. 1996. Learning English : Development and Diversity. London: Routledge.

[7] Prain et all. 2015. Personalizing Learning in Open - Plan Schools. Tasmania: Sense Publisher.

[8] Richards J.C. 1990. Curriculum Development in Language Teaching.Cambridge: Cambridge University Press.

[9] Swan, Michael \& Catherine Walter. 1990. The New Cambridge English Course: Teacher 2. Edinburg: Cambridge University Press.

[10] Tomlinson B. 2003. Developing Materials for Language Teaching. London: Great Britain. 